\title{
BIOSORPTION OF RHODAMINE B FROM AQUEOUS SOLUTION USING Araucaria angustifolia STERILE BRACTS
}

Bioadsorción de rodamina B de una solución acuosa utilizando brácteas estériles de Araucaria angustifolia

\section{Caroline Aparecida MATIAS ${ }^{1}$, Leonardo Jonathan GUISOLPHI GOMES DE OLIVEIRA ${ }^{1}$, Reginaldo GEREMIAS ${ }^{2}$ and Joni STOLBERG ${ }^{1 *}$}

${ }^{1}$ Federal University of Santa Catarina, Campus de Curitibanos, km 3 Rodovia Ulysses Gaboardi, Curitibanos, SC, CEP 89520-000, Brazil

${ }^{2}$ Federal University of Santa Catarina, Campus de Araranguá, Rodovia Governador Jorge Lacerda, 3201, Jardim das Avenidas, Araranguá, SC, CEP 88900-000, Brazil

*Corresponding author: joni.stolberg@ufsc.br

(Received: May 2018; accepted: March 2019)

Key words: Allium cepa, biosorbent, dye, pollution

\begin{abstract}
This study evaluated the removal of Rhodamine B dye by biosorption using Araucaria angustifolia sterile bracts. It also aimed to evaluate the treatment of a synthetic wastewater holding that dye. The biosorbent was characterized by infrared spectroscopy and thermogravimetric analysis. Equilibrium biosorption studies were made with the exposure of biosorbent to aqueous solutions of rhodamine $\mathrm{B}$ at different $\mathrm{pH}$ and initial concentrations. Removal tests for wastewater containing dye were performed with the bracts, and efficacy was assessed by the percentage of uptake of dye and bioassays. The infrared characterization showed peaks that are features to groups on carbohydrates and lignin, the major components in bract composition. The biosorption equilibrium studies presented acid media as the best condition for dye removal. The rate-controlling step of the biosorption was found to be governed by chemical processes (second order kinetics) and shown to be a heterogeneous biosorption based on the fit to the Freundlich equation model. The treatment for synthetic wastewater $(125 \mathrm{mg} / \mathrm{L})$ reduced the mass of rhodamine B by $96 \%$ and caused a decrease of toxic effects. The results show that sterile bracts can be considered as a low-cost alternative biosorbent to be applied on the removal of water pollutants and treatment of potentially toxic effluents.
\end{abstract}

Palabras clave: Allium cepa, bioadsorbente, colorante, contaminación

\section{RESUMEN}

En este estudio se evaluó la remoción del colorante rodamina B de soluciones acuosas por bioadsorción usando brácteas estériles de Araucaria angustifolia y su aplicación en el tratamiento de un agua residual sintética que contenía el colorante. El bioadsorbente se caracterizó por espectrometría infrarroja y termogravimetría. Se realizaron estudios de bioadsorción en equilibrio dejando el bioadsorbente en contacto con soluciones acuosas de rodamina $\mathrm{B}$ a diferentes $\mathrm{pH}$ y concentraciones iniciales. El tratamiento del colorante del agua residual sintética se realizó con las brácteas y la eficacia fue evaluada 
por el porcentaje de remoción del colorante y bioensayos. El análisis por infrarrojo arrojó señales típicas de los grupos funcionales de los carbohidratos y la lignina, los componentes principales en la constitución de las brácteas. Los estudios en equilibrio de bioadsorción mostraron que los medios ácidos son mejores para la remoción del colorante. La etapa de control de velocidad de la bioadsorción se rige por procesos químicos (cinética de segundo orden) y se muestra como un sistema heterogéneo basada en el ajuste de los datos experimentales al modelo de Freundlich. El tratamiento empleado para el agua residual que contenía el colorante $(125 \mathrm{mg} / \mathrm{L})$ redujo la masa de rodamina $\mathrm{B}$ en un $96 \%$ y disminuyeron los efectos de toxicidad. Los resultados muestran que las brácteas estériles pueden considerarse como un bioadsorbente alternativo de bajo costo para la eliminación de contaminantes del agua y el tratamiento de efluentes con potencial toxicidad.

\section{INTRODUCTION}

The industrial production of paper, textiles, rubber, plastic, paint, printing and leather requires large quantities of water and produces enormous volumes of effluents that can cause pollution in the receiving water. Rhodamine $\mathrm{B}$, a synthetically prepared xanthine dye, is widely used as a colorant in textile dyeing, leather and paint industries, and also as a biological stain in the laboratory. Human or animal exposure to rhodamine B has caused skin, eye and respiratory tract irritation, and has induced phototoxic and photoallergic reactions. Literature has reported carcinogenic, genotoxic and chronic effects caused by this dye (Lewis et al. 1981, Huang et al. 2016). Thereby, to avoid environmental pollution and health risk, it is necessary to treat dye wastewater correctly before discharge. The treatment or removal of pollutants from wastewater can be done with techniques such as coagulation, ion exchange, aerobic and anaerobic processes, electrolysis, advanced oxidative processes, activated sludge or biosorption. Biological materials, called biosorbents, have been employed to remove pollutants in waters or effluents. Barks, leaves, stalks and other low-cost forest or agricultural by-products have been used in biosorption processes (Gadd 2009, Bhatnagar and Sillampää 2010, Ali et al. 2012).

In the south of Brazil there are Araucaria forests, the main species being Araucaria angustifolia. This tree is an angiosperm that produces a cone with edible seeds covered by a lignocellulosic structure, called bract. Sterile bracts do not have seeds inside and could mean more than $80 \%$ of the lignocellulosic material in the cone (Michelon et al. 2012). Sterile bracts are mainly composed of lignin, hemicellulose and cellulose. All of them are biopolymers which have polar and nonpolar chemical groups that are able to interact with several different compounds.
This feature makes A. angustifolia sterile bracts a potential biosorbent to remedy industrial effluents containing dyes, including rhodamine $\mathrm{B}$.

This work aims to evaluate the use of $A$. angustifolia sterile bracts in the removal of rhodamine B from an aqueous solution by biosorption and to use those bracts for the removal of this dye from wastewater.

\section{EXPERIMENTAL PROCEDURE}

\section{Biosorbent preparation and characterization}

The sterile bracts of Araucaria cones were collected from sales points around the town of Curitibanos, located in upland areas of Santa Catarina state in the south of Brazil. The material was milled by a Wiley mill and sieved to granulometry between 20 to 60 mesh. The composition of the sterile bract raw (SR) was characterized in order to determine ash, total extractives and lignin contents (Sjöström and Alén 1999). The moisture was determined in an oven at temperature $103-105^{\circ} \mathrm{C}$ until constant weight; the ash content was made in an oven at $600{ }^{\circ} \mathrm{C}$ for $2.5 \mathrm{~h}$. The total extractive was obtained using a Soxhlet apparatus. Sequential extractions steps were of 6 $\mathrm{h}$ each with ethanol:toluene $(1: 2, \mathrm{v} / \mathrm{v})$, ethanol and dichloromethane, and washed with warm water at the end. Lignin was quantified by the Klason method (Nicholson et al. 2014). Briefly, the extractive-free sample was treated with $72 \%$ sulphuric acid and subsequently heated with dilute acid to hydrolyze the polysaccharides; after that, the solid residue was washed, dried and weighed. These experiments were made in duplicate. In order to remove soluble phenolic compounds present in the SR, it was boiled in distilled water for $2 \mathrm{~h}$, dried in an oven and put in a desiccator until its use; this material was henceforward called SB. The boiling step was needed to prevent soluble compounds from moving into the 
solution during the bath experiments (Michelon et al. 2012). The most important chemical groups present in the SR and SB were analyzed by Fourier transforminfrared spectroscopy (FTIR) (ABB, FTLA2000) and thermogravimetric analysis was used to explore the behavior of thermal biosorbent (Shimadzu, TGA-50). The point of zero charge (PZC) was determined by the salt addition method (Dahri et al. 2016) using $0.1 \mathrm{~mol} / \mathrm{L} \mathrm{NaCl}$. The $\mathrm{pH}$ of each salt solution $(\mathrm{pHi})$ was adjusted to a range of 3-10 using $0.1 \mathrm{~mol} / \mathrm{L} \mathrm{HCl}$ and $01 \mathrm{~mol} / \mathrm{L} \mathrm{NaOH}$. These solutions $(50 \mathrm{~mL})$ were mixed with biosorbent $(1 \mathrm{~g})$ and agitated until $\mathrm{pH}$ stabilization (pHf). The initial $\mathrm{pH}(\mathrm{pHi})$ and final $\mathrm{pH}(\mathrm{pHf})$ were measured and a diagram was created with the $\mathrm{pHi}$ versus $\mathrm{pHi}$-pHf values. The $\mathrm{PZC}$ value was obtained from this diagram at the point where the data curve intercepts the abscissa and the value of $\mathrm{dpH}$ becomes equal to zero.

\section{Batch biosorption and models simulation}

Both experiments were carried out by mixing 0.50 $\mathrm{g}$ of biosorbent with $50 \mathrm{~mL}$ of rhodamine B (Sigma) aqueous solution in $150 \mathrm{~mL}$ borosilicate Erlenmeyer flasks (Matias et al. 2013). Solutions were agitated using an orbital shaker at $150 \mathrm{rpm}$ (Cientec, CT712RTN) and a controlled temperature of $20{ }^{\circ} \mathrm{C}$. All samples were prepared in duplicate. The effects of contact time $(\mathrm{Ci}=10 \mathrm{mg} / \mathrm{L}), \mathrm{pH}$ (3 to $10 ; \mathrm{C}_{\mathrm{i}}=$ $10 \mathrm{mg} / \mathrm{L}$ ) and initial dye concentration (2.5 to 220 $\mathrm{mg} / \mathrm{L}$ ) on the biosorption process were investigated. The amount of dye removed by the biosorbent at equilibrium $\left(q_{\mathrm{e}}[\mathrm{mg} / \mathrm{g}]\right)$ was calculated (equation 1) by analyzed filtrate mixture on $553 \mathrm{~nm}$ using visible spectroscopy (Bel, SP2000).

$q_{\mathrm{e}}=\left(C_{\mathrm{i}}-C_{\mathrm{e}}\right) \mathrm{V} / \mathrm{m}$

where $C_{\mathrm{i}}$ and $C_{\mathrm{e}}$ are the initial and equilibrium dye concentrations $(\mathrm{mg} / \mathrm{L})$, respectively, $V$ is the dye solution used (L) and $m$ is the mass of biosorbent used (g).

To investigate the kinetic behavior of the biosorption, experimental data obtained for the contact time was applied to the kinetic models of pseudo first order (equation 2) and pseudo second order (equation 3) (Lagergren 1898, Ho and McKay 1998):

$q_{\mathrm{t}}=q_{\mathrm{e}}\left(1-e^{\mathrm{k} 1 \cdot \mathrm{t}}\right)$

$q_{\mathrm{t}}=t /\left(1 / k_{2} \cdot q_{\mathrm{e}}^{2}\right)+\left(t / q_{\mathrm{e}}\right)$

If $q_{\mathrm{t}}$ is the amount of dye removed in the time considered $(\mathrm{mg} / \mathrm{g}), q_{\mathrm{e}}$ is the amount of dye removed by the biosorbent at equilibrium $(\mathrm{mg} / \mathrm{g}), t$ is the time (min) and $k_{1}$ and $k_{2}$ the constants of speed for the kinetics of pseudo first order $\left(\mathrm{min}^{-1}\right)$ and pseudo second order $(\mathrm{g} / \mathrm{mg} \times \mathrm{min})$, respectively. The data of the equilibrium experiments for initial concentration were tested in Langmuir (IV) and Freundlich (V) isotherm models (Freundlich 1906, Langmuir 1916):

$q e=\left(Q \cdot K_{\mathrm{L}} \cdot C_{\mathrm{e}}\right) /\left(1+K_{\mathrm{L}} \cdot C_{\mathrm{e}}\right)$

$q e=K_{\mathrm{F}} \cdot C_{\mathrm{e}}^{\beta}$

where $q_{\mathrm{e}}$ represents the mass removed by biosorbent at chemical equilibrium $(\mathrm{mg} / \mathrm{g}), Q$ the maximal biosorption capacity $(\mathrm{mg} / \mathrm{g}), C_{\mathrm{e}}$ the dye concentration at equilibrium $(\mathrm{mg} / \mathrm{L}), K_{\mathrm{L}}(\mathrm{L} / \mathrm{mg})$, and $K_{\mathrm{F}}\left(\mathrm{mg}^{1-\beta} / \mathrm{g} . \mathrm{L}^{\beta}\right)$ the Langmuir and Freundlich equilibrium constants, respectively. $\beta$ is a thermodynamical parameter related to mutual interaction among molecules of dye absorbed.

The experimental data to kinetics and biosorption isotherm models were simulated by a non-linear method using tools provided in the Microcal Origin 5.0 software. Simulated $q_{\mathrm{e}}\left(q_{\mathrm{e}}\right.$, sil $)$ were generated from formulae of various kinetics or isotherm models. Both $q_{\mathrm{e}}$, sil and the experimental data $\left(q_{\mathrm{e}}\right)$ were fitted into a chi-square test $\left(\chi^{2}\right)$ and average relative error equations (ARE) for error analysis (equation 6). The smallest value indicates the least error model into to the experimental data (Kooh et al. 2016).

$\mathrm{ARE}=\frac{100}{n} \sum_{\mathrm{i}=1}^{n}\left|\frac{q_{\mathrm{ie}}-q_{\text {iesil }}}{q_{\text {ie }}}\right|$

\section{Wastewater treatment and toxicity assay}

In order to evaluate the biosorbent application to the removal of dye from wastewater, a sample of commercial rhodamine B was obtained from a local timber industry site. A commercial rhodamine B solution was prepared in laboratory as a synthetic wastewater and characterized by visible spectroscopy scanning (Bel, SP2000). The treatment was made using biosorbent in a bath system $(10 \mathrm{~g} / \mathrm{L})$ and its effectiveness was evaluated by toxicity bioassays. The inhibition of root growth in Allium cepa (onion) was observed to examine the sub-chronic toxicity in untreated and treated synthetic wastewater according to Fiskesjö (1993). Individuals of $A$. серa $(\mathrm{n}=6)$ were exposed to $50 \mathrm{~mL}$ of untreated and treated synthetic wastewater. Commercial mineral water was used as the negative control. After 7 days of exposure, the relative inhibition of root growth was calculated and expressed as a percentage. Statistical analysis of the 
sub-chronic toxicity in A. cepa was performed using analysis of variance (ANOVA) complemented with the Student-Newman-Keuls (SNK) and Dunnet tests. The results were expressed as mean $\pm \mathrm{SD}$.

\section{RESULTS AND DISCUSSION}

\section{Biosorbent characterization}

The composition of SR was as follows: ash $1.88 \%$, total extractives $6.06 \%$, lignin $45.38 \%$ and holocellulose (hemicellulose + cellulose) $46.68 \%$ (calculated by the difference). These results are recorded in literature in relation to the estimated composition of the bark of conifers (Rowell 2013). Regarding the infrared spectroscopy analysis, both SR and SB spectrums (Fig. 1) presented strong signal bands to $\mathrm{OH}$ groups intermolecular interaction $\left(3415 \mathrm{~cm}^{-1}\right)$ and $\mathrm{C}-\mathrm{H}$ bond stretching $\left(2923 \mathrm{~cm}^{-1}\right)$. The peaks at 1510 and $1610 \mathrm{~cm}^{-1}$ correspond to the $\mathrm{C}=\mathrm{C}$ aromatic ring skeleton stretching vibration and the peak at $1054 \mathrm{~cm}^{-1}$ corresponds to the C-O-C pyranose stretching. The peaks obtained are features to groups on carbohydrates and lignin, the major components in bract composition (Silverstein et al. 2005, Kumar et al. 2014, Liu et al. 2014).

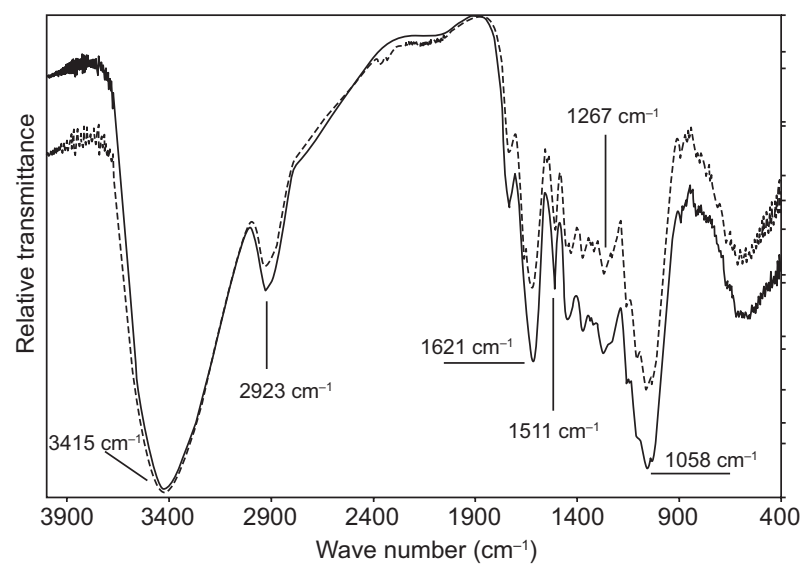

Fig. 1. Fourier transform-infrared spectra of sterile bract raw (solid line) and sterile bract boiled (dashed line)

These signals show the presence of important polar groups in the biosorbent chemical composition. The polar groups can strongly interact by hydrogen-bonding and/or dipole-dipole interactions with compounds that possess, for example, $\mathrm{O}-\mathrm{H}$ and $\mathrm{N}-\mathrm{H}$, in their chemical structures. The SR spectrum is similar to SB, indicating that the main lignocellulosic groups of biosorbent were not modified by the boiled treatment. Differential thermogravimetric analysis (DTGA) showed that SR has a lower thermal stability $\left(182{ }^{\circ} \mathrm{C}\right)$ than SB $\left(204{ }^{\circ} \mathrm{C}\right)($ Fig. 2). This higher degradation temperature for SB can be attributed to boiled treatment that might remove or degrade the phenolic compounds. In fact, when SR is put in water, the solution becomes colored after a few minutes. This happens because its soluble phenolic compounds move to the aqueous solution. Boiling removed these compounds from SR and reduced its mass nearly by $14 \%$. Because of these facts, only SB has been used in rhodamine $\mathrm{B}$ biosorption studies.

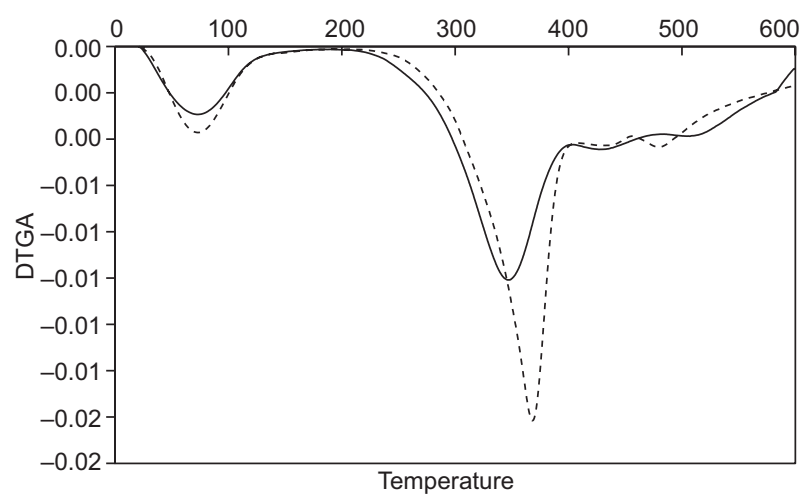

Fig. 2. Differential thermogravimetric analysis curves of the sterile bract raw (solid line) and sterile bract boiled (dashed line)

\section{Rhodamine B biosorption studies}

The chemical balance of biosorption between the biosorbent and the dye was reached after $2 \mathrm{~h}$ of contact. This time was used for all the equilibrium experiments performed in this work. The effect of $\mathrm{pH}$ on biosorption of rhodamine $\mathrm{B}$ by $\mathrm{SB}$ is showed in figure 3. The removal capacity of rhodamine $\mathrm{B}$ by $\mathrm{SB}$ was greater than $80 \%$ at $\mathrm{pH}$ lower than 5 . The minimum removal occurred at $\mathrm{pH} 10$ with approximately $30 \%$.

It is evident from the above that $\mathrm{pH}$ has a great influence on the biosorption behavior of naturally occurring biosorbents as well as on some adsorvates. The protonation or deprotonation of functional groups present in the biosorbent and in the dye can be $\mathrm{pH}$-dependent and influence the attraction effects between charges involved in the biosorption process. For $\mathrm{SB}$, the $\mathrm{PZC}$ was obtained at $\mathrm{pH} 6$. This indicates that the biosorbent has its surface charged positively in a medium in which the $\mathrm{pH}$ is below 6 . Above $\mathrm{pH}$ 6 , its surface has predominantly negative electric charge. Rhodamine $\mathrm{B}$ is described as a cationic dye; 


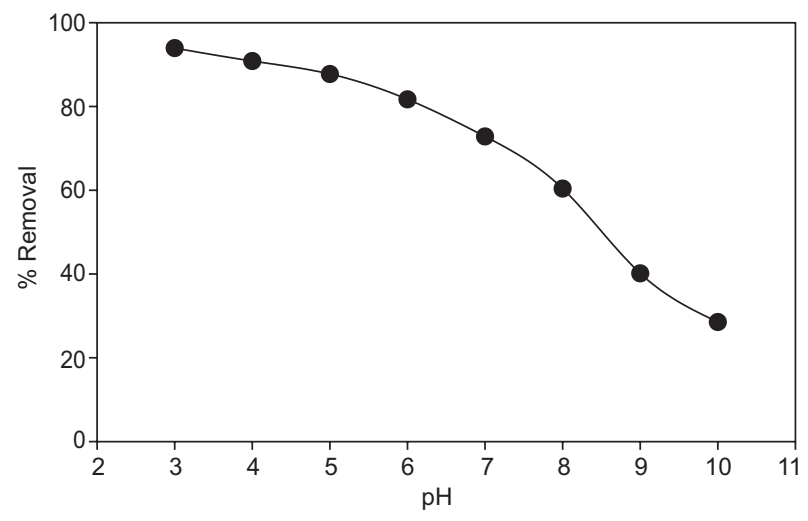

Fig. 3. Effect of $\mathrm{pH}$ on the removal of rhodamine $\mathrm{B}$ by sterile bract boiled $\left(C_{\mathrm{i}}=10 \mathrm{mg} / \mathrm{L} ; 20^{\circ} \mathrm{C}\right)$

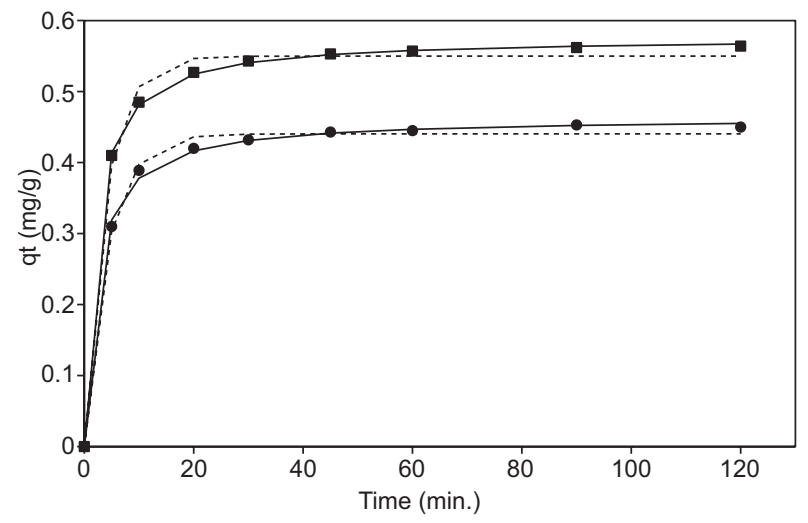

Fig. 4. Effect of contact time and comparison of different kinetic models for rhodamine $\mathrm{B}$ onto sterile bract boiled $\left(C_{\mathrm{i}}=10 \mathrm{mg} / \mathrm{L} ; 20^{\circ} \mathrm{C}\right)$ in $\mathrm{pH} 4(\boldsymbol{\bullet})$ and $8(\bullet)$ (pseudo first order in dash and pseudo second order in plain)

however, the carboxyl group of its structure has $\mathrm{pKa}$ around 3.7 which favors interactions of charge with the biosorbent in acidic $\mathrm{pH}$. For a medium in which the $\mathrm{pH}$ is greater than 3.7, the zwitterionic form of the dye causes the dimerization of rhodamine B. The morphology of the sterile bract has been recently described as highly porous and with a rough surface (Carmo et al. 2017), and a dye dimerization can reduce biosorption by limiting its access to the sites of biosorbent interaction located within the pores (Huang et al. 2016). Indeed, several studies have described rhodamine $\mathrm{B}$ as having a higher biosorption capacity in acid media and at $\mathrm{pH}$ below the PZC of the biosorbent (Hii et al. 2009, Dahri et al. 2016, Kooh et al. 2016).

Based on this result, we studied the kinetics of dye biosorption by SB at $\mathrm{pH} 4$ and 8. Data were applied to the kinetic models of pseudo first and pseudo second orders using non-linear regression (Fig. 4).
The results confirmed a higher biosorption capacity at equilibrium for acidic $\mathrm{pH}\left(q_{\mathrm{e}}=0.564 \mathrm{mg} / \mathrm{g}\right)$ to the detriment of the alkaline medium $\left(q_{\mathrm{e}}=0.450 \mathrm{mg} / \mathrm{g}\right)$. In both $\mathrm{pH}$ values the best data fit was obtained for the kinetic model of pseudo second order, in which the lowest $\chi^{2}$ and ARE values were obtained (Table I). This indicated that the rate-controlling step of the biosorption process may be governed by chemical processes, which involve valency forces through the sharing or exchange of electrons between the biosorbent and adsorbate as covalent forces, and ion exchange (Ho 2006).

TABLE I. PARAMETERS FOR THE KINETICS MODEL

\begin{tabular}{|c|c|c|c|}
\hline \multicolumn{2}{|c|}{ Pseudo first order } & \multicolumn{2}{|c|}{ Pseudo second order } \\
\hline \multicolumn{4}{|c|}{$\mathrm{pH} 4$} \\
\hline$q_{\mathrm{e}, \mathrm{sil}}(\mathrm{mg} / \mathrm{g})$ & $\begin{array}{c}0.550 \\
( \pm 0.00598)\end{array}$ & $q_{\mathrm{e}, \mathrm{sil}}(\mathrm{mg} / \mathrm{g})$ & $\begin{array}{c}0.576 \\
( \pm 0.00144)\end{array}$ \\
\hline$k_{1}\left(\min ^{-1}\right)$ & $\begin{array}{c}0.255 \\
( \pm 0.0184)\end{array}$ & $k_{2}(g / m g . m i n)$ & $\begin{array}{c}0.883 \\
( \pm 0.0228)\end{array}$ \\
\hline$\chi^{2}\left(10^{-5}\right)$ & 21.0 & $\chi^{2}\left(10^{-5}\right)$ & 0.703 \\
\hline ARE & 0.0328 & ARE & 0.0111 \\
\hline \multicolumn{4}{|c|}{ pH 8} \\
\hline$q_{\mathrm{e}, \mathrm{sil}}(\mathrm{mg} / \mathrm{g})$ & $\begin{array}{c}0.440 \\
( \pm 0.00425)\end{array}$ & $q_{\mathrm{e}, \text { sil }}(\mathrm{mg} / \mathrm{g})$ & $\begin{array}{c}0.464 \\
( \pm 0.00352)\end{array}$ \\
\hline$k_{1}\left(\min ^{-1}\right)$ & $\begin{array}{c}0.233 \\
( \pm 0.0141)\end{array}$ & $k_{2}(g / m g . m i n)$ & $\begin{array}{c}0.951 \\
( \pm 0.0688)\end{array}$ \\
\hline$\chi^{2}\left(10^{-5}\right)$ & 11.0 & $\chi^{2}\left(10^{-5}\right)$ & 4.00 \\
\hline ARE & 0.193 & ARE & 0.00753 \\
\hline
\end{tabular}

$q_{\mathrm{e}}$, sil: amount of dye removed by the biosorbent at equilibrium simulation $(\mathrm{mg} / \mathrm{g}), k_{1}$ : pseudo-first-order rate constant, $k_{2}$ : pseudo-second-order rate constant, $\chi^{2}$ : chi-square test, ARE: average relative error

The equilibrium of dye biosorption by SB was studied at $\mathrm{pH} 4$ and 8. Data were fitted to the Langmuir and Freundlich equations using non-linear regression (Figs. 5 and 6). For both $\mathrm{pH}$ values, the best fit was obtained by the Freundlich model, which achieved the smallest $\chi^{2}$ and ARE values as well (Table II). The disagreement with the Langmuir model might occur due to the fact that the hypothesis of constant energy biosorption is not performed, because the biosorbent surface is heterogeneous. The $K_{\mathrm{F}}$ constant calculated for the experiment at $\mathrm{pH} 4$ had a higher value than that obtained for the biosorption of the dye at $\mathrm{pH} 8$. 


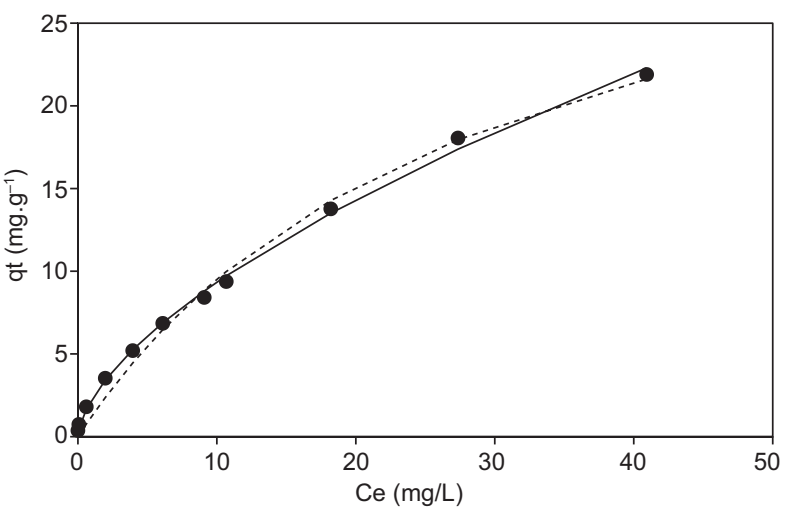

Fig. 5. Isotherm of rhodamine $B$ biosorption on sterile bract boiled in $\mathrm{pH} 4\left(C_{\mathrm{i}}=2.5\right.$ to $\left.220 \mathrm{mg} / \mathrm{L} ; 20^{\circ} \mathrm{C}\right)$. Non-linearized Langmuir isotherm (dashed line) and Freundlich (solid line) isotherm

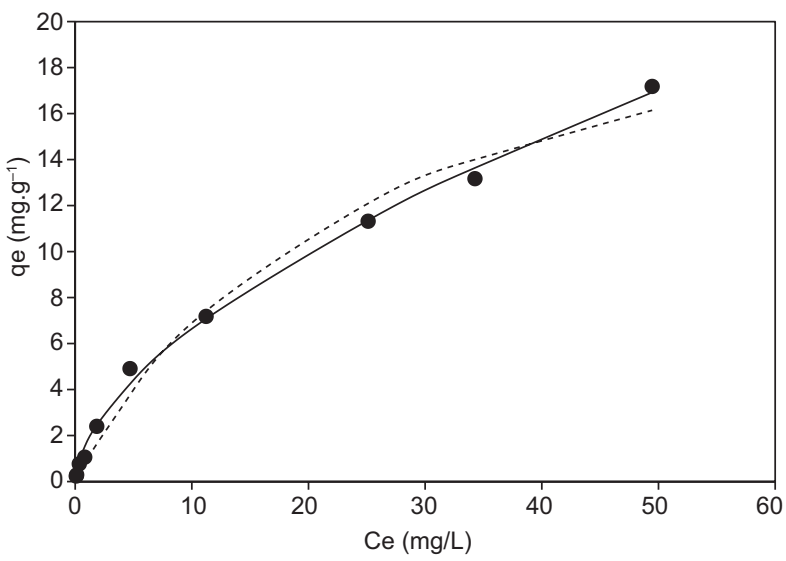

Fig. 6. Isotherm of rhodamine $\mathrm{B}$ biosorption on sterile bract boiled in $\mathrm{pH} 8\left(C_{\mathrm{i}}=2.5\right.$ to $\left.220 \mathrm{mg} / \mathrm{L} ; 20^{\circ} \mathrm{C}\right)$. Non-linearized Langmuir isotherm (dashed line) and Freundlich (solid line) isotherms

This confirms a higher removal capacity of rhodamine $\mathrm{B}$ by the biosorbent under acidic conditions. Other studies have also described the removal of dye by biosorbents as heterogeneous and a greater capacity for acid media. The removal of rhodamine B by mango endocarp (Inyinbor et al. 2015) and lignin from sugarcane bagasse (Abou-Gamra and Medien 2013) showed a biosorption intensity (denoted by parameter $\beta$ ) of a very similar value to that obtained in the present study $(0.618 \pm 0.0151)$. This parameter is also used to estimate the biosorbent surface heterogeneity. The higher the $\beta$ value, the greater the surface heterogeneity (Vázquez et al. 2007, Lacerda et al. 2015).

\section{Evaluation of wastewater treatment}

The evaluation of SB to treat wastewater was made using a synthetic wastewater containing
TABLE II. CALCULATED PARAMETERS FOR LANGMUIR AND FREUNDLICH ISOTHERMS

\begin{tabular}{lclc}
\hline \multicolumn{3}{c}{ Langmuir } & $\mathrm{pH} 4$ \\
\hline$K_{\mathrm{L}}(L / m g)$ & $\begin{array}{c}0.0350 \\
( \pm 0.00523)\end{array}$ & $K_{\mathrm{F}}\left(m g^{1-\beta} / g \cdot L^{\beta}\right)$ & $\begin{array}{c}2.25 \\
( \pm 0.110)\end{array}$ \\
\hline$Q(m g / g)$ & $\begin{array}{c}36.7 \\
( \pm 3.07)\end{array}$ & $\beta$ & $\begin{array}{c}0.618 \\
( \pm 0.0151)\end{array}$ \\
\hline$\chi^{2}$ & 0.516 & $\chi^{2}$ & 0.136 \\
\hline $\mathrm{ARE}$ & 19.6 & $\mathrm{ARE}$ & 5.39 \\
\hline & $\begin{array}{c}0.0384 \\
( \pm 0.00930)\end{array}$ & $K_{\mathrm{F}}\left(m g^{1-\beta} / g . L^{\beta}\right)$ & $\begin{array}{c}1.71 \\
( \pm 0.127)\end{array}$ \\
\hline$K_{\mathrm{L}}(L / m g)$ & $\begin{array}{c}24.6 \\
( \pm 2.77)\end{array}$ & $\beta$ & $\begin{array}{c}0.588 \\
( \pm 0.0211)\end{array}$ \\
\hline$Q(m g / g))$ & 0.583 & $\chi^{2}$ & 0.133 \\
\hline$\chi^{2}$ & 12.3 & $\mathrm{ARE}$ & 6.46 \\
\hline $\mathrm{ARE}$ & & &
\end{tabular}

$K_{\mathrm{L}}$ : Langmuir isotherm constant, $K_{\mathrm{F}}$ : Freundlich isotherm constant, $Q$ : Langmuir biosorption capacity, $\beta$ : Freundlich thermodynamical parameter, $\chi^{2}$ : chi-square test, ARE: average relative error

commercial rhodamine B obtained from a local timber industry where the dye is dissolved in water $(125 \mathrm{mg} / \mathrm{L})$ and is stored in a big tank, which is used to dye plywood by dipping. Plywood is a sheet material manufactured from thin layers of softwood and it is dyed to identify its commercial application. The rhodamine B commercial sample was investigated by spectroscopy and showed similar characteristic bands as the analytical grade dye, which confirm its chemical identity. Treatment of synthetic wastewater containing rhodamine B within SB removed $96 \%$ in the mass of dye $\left(q_{\mathrm{e}}=4.95 \mathrm{mg} / \mathrm{L}\right)$. After this, the treatment performance was evaluated by toxicity bioassays. Untreated wastewater containing the dye caused significant growth inhibition on roots of $A$. серa (Fig. 7). This phytotoxic effect could be related to bioaccumulation of rhodamine $\mathrm{B}$ in plants and interactions with specific areas in the meristematic cell nucleus. Due to this, different kinds of physiological, biochemical and molecular effects can be initiated, including mitotic activity change, nuclear aberration (e.g., micronucleus, nuclear buds and bridged nuclei) and oxidative stress (Tan et al. 2014). 


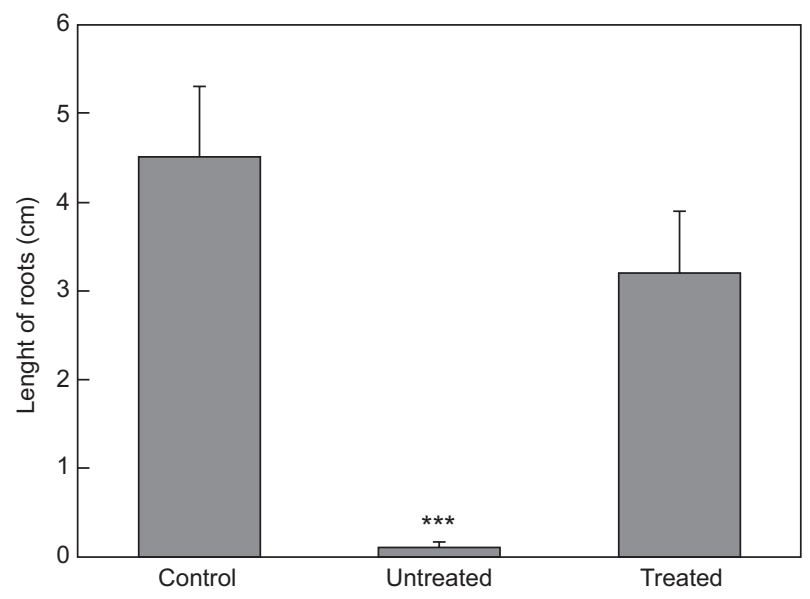

Fig. 7. Length of roots in A. cepa. ***Significant difference compared to the negative control and treated dye solution $(\mathrm{p}<0.001)$

\section{CONCLUSIONS}

Boiling of sterile bract of $A$. angustifolia seems to preserve chemical groups that could be acting on rhodamine B biosorption. However, this boiled bract has a higher thermal stability than the unboiled one. Biosorption equilibrium studies identified the acid medium as the best condition to dye removal. The ratecontrolling step of the biosorption process was found to be governed by chemical processes and shown to be heterogeneous, based on the fit to the Freundlich equation model. The treatment of commercial rhodamine $\mathrm{B}$ by SB was successful in reducing toxicity in the $A$. cepa root. The results showed that bract may be considered as a low cost alternative biosorbent to be applied in the removal of water pollutants and the treatment of potentially toxic effluents.

\section{REFERENCES}

Abou-Gamra Z.M. and Medien H.A.A. (2013). Kinetic, thermodynamic and equilibrium studies of Rhodamine $\mathrm{B}$ adsorption by low cost biosorbent sugar cane bagasse. Eur. Chem. Bull. 2 (7), 417-422.

DOI: 10.17628/ECB.2013.2.417-422

Ali I., Asim M. and Khan T.A. (2012). Low cost adsorbents for the removal of organic pollutants from wastewater. J. Environ. Manage. 113, 170-183.

DOI: 10.1016/j.jenvman.2012.08.028

Bhatnagar A. and Sillampää M. (2010). Utilization of agroindustrial and municipal waste materials as potential adsorbents for water treatment-A review. Chem. Eng. J. 157 (2-3), 277-296. DOI: 10.1016/j.cej.2010.01.007
Carmo S.N., Meriba J., Diasb A.N., Stolberg J., Budziak D. and Carasek E. (2017). A low-cost biosorbentbased coating for the highly sensitive determination of organochlorine pesticides by solid-phase micro extraction and gas chromatography-electron capture detection. J. Chromatogr. A. 1525, 23-31.

DOI: $10.1016 /$ j.chroma.2017.10.018

Dahri M.K., Kooh M.R.R. and Lim L.B.L. (2016). Remediation of rhodamine $\mathrm{B}$ dye from aqueous solution using Casuarina equisetifolia cone powder as a lowcost adsorbent. Adv. Chem. Phys. 2016, 1-7.

DOI: $10.1155 / 2016 / 9497378$

Fiskesjö G. (1993). The Allium test in wastewater monitoring. Environ. Toxicol. 8 (3), 291-298.

DOI: $10.1002 /$ tox.2530080306

Freundlich H.M.F. (1906). Over the adsorption in solution. J. Phy. Chem. 57, 385-470.

Gadd G.M. (2009). Biosorption: Critical review of scientific rationale, environmental importance and significance for pollution treatment. J. Chem. Technol. Biotechnol. 84 (1), 13-28.

DOI: $10.1002 /$ jctb. 1999

Hii S., Yong S. and Wong C. (2009). Removal of rhodamine B from aqueous solution by sorption on Turbinaria conoides (Phaeophyta). J. Appl. Phycol. 21 (5), 625-631. DOI: 10.1007/s10811-009-9448-3

Ho Y.S. and McKay G. (1998). Sorption of dye from aqueous solution by peat. Chem. Eng. J. 70 (2), 115-124. DOI: 10.1016/S0923-0467(98)00076-1

Ho Y. (2006). Review of second-order models for adsorption systems. J. Hazard. Mater. 136 (3), 681-689. DOI: 10.1016/j.jhazmat.2005.12.043

Huang Y., Zheng X., Feng S., Guo Z. and Liang S. (2016). Enhancement of rhodamine $B$ removal by modifying activated carbon developed from Lythrum salicaria $\mathrm{L}$. with pyruvic acid. Colloids Surf. A Physicochem. Eng. Asp. 489, 154-162.

DOI: $10.1016 /$ j.colsurfa.2015.10.050

Inyinbor A.A., Adekola F.A. and Olatunji, G. A. (2015). Adsorption of rhodamine B dye from aqueous solution on Irvingia gabonensis biomass: Kinetics and thermodynamics studies. S. Afr. J. Chem. 68, 115-125. DOI: 10.17159/0379-4350/2015/v68a17

Kooh M.R.R., Lim L.B.L., Lim L.H. and Dahri M.K. (2016). Separation of toxic rhodamine B from aqueous solution using an efficient low-cost material, Azolla pinnata, by adsorption method. Environ. Monit. Assess. $188,108$. DOI: $10.1007 / \mathrm{s} 10661-016-5108-7$

Kumar A., Negy Y.S., Choudhary V. and Bhardwaj N.K. (2014). Characterization of cellulose nanocrystals produced by acid-hydrolysis from sugarcane bagasse as agro-waste. J. Mater. Phys. Chem. 2, 1-8. 
Lacerda V. S., López-Sotelo J. B., Correa-Guimarães A., Hernández-Navarro S., Sánchez-Báscones M., NavasGracía L. M., Martín-Ramos P. and Martín-Gil J. (2015). Rhodamine B removal with activated carbons obtained from lignocellulosic waste. J. Environ. Manage. 155, 67-76. DOI: 10.1016/j.jenvman.2015.03.007

Lagergren S. (1898). About the theory of so-called adsorption of soluble substances. K. Sven. vetensk.akad. Handl. 24 (4), 1-39.

Langmuir I. (1916). The constitution and fundamental properties of solids and liquids. Part I. Solids. J. Am. Chem. Soc. 38 (11), 2221-2295.

DOI: $10.1021 / \mathrm{ja} 02268 \mathrm{a} 002$

Lewis I.L., Patterson R.M. and McBay H.C. (1981). The effects or rhodamine B on the chromosomes of Muntiacus muntjac. Mutat. Res. 88 (2), 211-216. DOI: $10.1016 / 0165-1218(81) 90020-3$

Liu R., Peng Y., Cao J. and Chen Y. (2014). Comparison on properties of lignocellulosic flour/polymer composites by using wood, cellulose, and lignin flours as fillers. Compos. Sci. Technol. 103, 1-7.

DOI: $10.13140 / 2.1 .3440 .8008$

Matias C.A., Oliveira L.J.G.G., Geremias R. and Stolberg J. (2013). Remoção de rodamina B por biosorção utilizando brácteas de Araucaria angustifolia. Proceedings. 65th SBPC Annual Meeting. Recife. Brazil. June 21-26 [online]. http://www.sbpcnet.org.br/livro/65ra/ resumos/resumos/8515.htm 18/02/2019
Michelon F., Branco C.S., Calloni C., Giazzon I., Agostini F., Spada P.K.W. and Salvador M. (2012). Araucaria Angustifolia: A potential nutraceutical with antioxidant and antimutagenic activities. Curr. Nutr. Food Sci. 8 (3), 155-159. DOI: 10.2174/157340112802651103

Nicholson D.J., Leavitt A.T. and Francis R.C. (2014). A three-stage Klason method for more accurate determination of hardwood lignin content. Cell. Chem. Technol. 48 (1-2), 53-59.

Rowell R.M. (2013). Handbook of wood chemistry and wood composites. 2nd ed. CRC Press, Boca Raton, USA, 687 pp.

Silverstein R.M., Webster F.X. and Kiemle D.J. (2005). Spectrometric identification of organic compounds. 7th ed. John Willian and Sons, Hoboken, USA, 502 pp.

Sjöström E. and Alén R. (1999). Analytical methods in wood chemistry, pulping and papermaking. Springer, Berlin, Germany, 293 pp.

Tan D., Bai B., Jiang D., Shi L., Cheng S., Tal D. and Ji S. (2014). Rhodamine B induces long nucleoplasmic bridges and other nuclear anomalies in Allium cepa root tip cells. Environ. Sci. Pollut. Res. 21 (5), 3363-3370. DOI: $10.1007 / \mathrm{s} 11356-013-2282-9$

Vázquez G., González-Álvarez J., García A.I., Freire M.S. and Antorrena G. (2007). Adsorption of phenol on formaldehyde-pretreated Pinus pinaster bark: Equilibrium and kinetics. Bioresour. Technol. 98 (8), 1535-1540. DOI: 10.1016/j.biortech.2006.06.024 